\title{
Archaeological and Geological Approaches in the Work on the Project "Materiality and ancient environmental knowledge reconstruction trough archaeological chemistry analytical techniques (RE:MATRIARCHES)"
}

\author{
Boyan Dumanov $^{1}$, Zhivko Uzunov ${ }^{1}$, Bilyana Kostova ${ }^{2}$, Irena Dimitrova ${ }^{1}$, Ventsislava \\ Ivanova $^{1}$ \\ ${ }^{I}$ New Bulgarian University, Department of Archaeology, 21 Montevideo Blvd., Sofia, Bulgaria \\ ${ }^{2}$ New Bulgarian University, Department of Natural Sciences, 21 Montevideo Blvd., Sofia, Bulgaria \\ bkostova@nbu.bg
}

\section{Археологически и геоложки подходи при работата по проект „Реконструкция на материалната култура и знанията за древната околна среда чрез методите на археологическата химия (акроним: RE:MATRIARCHES)“}

\author{
Боян Думанов ${ }^{1}$, Живко Узунов ${ }^{1}$, Биляна Костова ${ }^{2}$, Ирена Димитрова $^{1}$, Венцислава \\ Иванова 1 \\ ${ }^{1}$ Нов български университет, департамент „Археология“, бул. Монтевидео 21, гр. София \\ ${ }^{2}$ Нов български университет, департамент „Природни науки“, бул. Монтевидео 21, гр. София \\ bkostova@nbu.bg
}

\begin{abstract}
The study discusses new approaches designed for the purposeful selection of archeological and geological sites and sample collection for analysis via archaeological chemistry techniques. The approaches discussed provide opportunities for coherent interpretation of analytical data in view of the project's objectives: gaining fundamental knowledge of material culture in different archaeological periods as well as of people's knowledge of the environment in ancient times.
\end{abstract}

Key words: archaeological and geological approaches, fieldwork planning, fieldwork, post-fieldwork, sample collection

Резюме: Създадени са подходи за целенасочен подбор на археологически и геоложки обекти и събиране на проби за изследване чрез методите на археологическа химия. Тези подходи позволяват методическа работа, която предоставя възможност за адекватна интерпретация на аналитични данни за постигане на целите на проекта - фундаментални познания за материалната култура в различни археологически периоди и познания на хората за древната среда.

Ключови думи: археологически и геоложки подход, подготовка за теренна работа, теренна работа, камерална работа, събиране на образци

\section{Introduction}

The project's objective is to obtain new data on material culture (archaeological synthetic materials - ceramic building materials, pottery, cement composites, and slags) and people's 
knowledge for the ancient environment (geological local raw materials used for building, production of materials, household items, technology development, etc.) in the area of the Sarnena Sredna Gora Mountain and the southern foothills.

In view of the interdisciplinarity of the project, the accomplishment of the research objectives follows three approaches. Archaeological and geological approaches are applied to sample collection. The investigation of the composition and structure of archaeological and geological samples through the archaeological chemistry approach is applied to achieve the final project objective.

There are many publications in the literature on archaeological chemistry presenting the approach to analytical methods choice, as well as many examples of specific experimental results interpretation [Glascock et al., 2006; Goffer, 2007; Issi et al., 2013; Krapukaitytè et al., 2008; Naseerutheen et al., 2013; Neff, 1993; Palanivel et al., 2009; Palanivel Ret al., 2011; Pollard and Heron, 2008; Roberts and Thornton, 2013; Sáncheza et al., 2019]. Based on the state of art, the following analytical techniques have been selected for the current project: X-ray fluorescence spectrometry, powder X-ray powder diffraction, Fourier transform infrared spectroscopy Mössbauer spectroscopy, thermal analysis).

Regarding the archaeological and geological approaches, specific scientific sources in the field are yet to appear. Such approaches are essential, as they carry out the activities for sample collecting, necessary for achieving the project objectives. These activities include fieldwork planning, actual fieldwork (simply referred to as fieldwork), and post-fieldwork.

This paper deals with created archaeological and geological approaches and the results obtained from their application.

\section{Approaches for sample collection \\ 1.1. Archaeological approach}

The created archaeological approach includes:

- preparation of bibliographic references about the history of archaeological research in the Sarnena Sredna Gora Mountain and the southern foothills to select suitable archaeological sites;

- fieldwork for sample collection of archaeological materials from the selected sites;

- chronological determination of the collected samples;

- archaeological samples cataloging;

- creating a set of representative samples for analytical investigation.

\subsection{Geological approach}

The created geological approach includes:

- bibliographic reference preparation for geological settings in the area of interest to search the contemporary locations situated on the earth surface of potential raw materials for archaeological materials preparation;

- fieldwork to search and collect raw material for laboratory studies in the area under study;

- geographical linking of rock deposits with selected archaeological sites;

- identification of rock materials used as a building material for the construction of walls of houses, fortress walls, etc.

- description of collected samples;

- creating a set of representative samples for analytical investigation. 


\section{Results and discussion \\ 2.1. Fieldwork planning}

The project is a continuation of our previous successfully implemented project supported by the Bulgarian Science Research Fund in 2014-2017: "Center for localization and experimental reconstruction of ancient roads and habitats through the methods of spatial analysis and archaeometry". During the work on the project in 2014-2017, 159 archeological sites from 7 archeological periods were registered [Dumanov et al. 2016; Dumanov et al. 2017b; Uzunov, 2017a; Uzunov et al. 2017b]. Based on these results, the prepared bibliographic references and data from the Archaeological Map of Bulgaria of the previously registered and studied archaeological sites, a preliminary selection of archaeological sites suitable for the archaeological material collection was created.

The selection of archaeological sites was made in view of two criteria:

- sites with a high probability of finding suitable material to achieve the objectives of the project, namely building materials (mortar, ceramic building materials), pottery, traces of iron production (slag);

- sites with material of different archaeological periodization.

The selected archaeological sites are allocated within 7 archaeological periods (Chalcolithic, Bronze Age, Iron Age, Roman Age, Antiquity, Medieval, and Bulgarian Renaissance). Most of them were registered during our previous project. To supplement the set of samples, additional sites of archaeological importance for this project have been added. These sites date back to the Roman age and Late Antiquity and were chosen due to the preserved archaeological structures on the earth's surface of stone walls with mortar and clay plasters, as well as ceramic fragments (building ceramic and pottery). In the study area, such archaeological structures have been established only from these two epochs, due to the use of stone for construction during this time [Uzunov et al., 2017b]. Although we have registered sites from the region of Gorno Novo selo village, the additional sites were chosen due to their archaeological importance as part of the settlement complex, defined as regional management, economic and religious center in the central part of Sarnena Sredna Gora [Dumanov, 2017a].

The geological background of the area has been studied via bibliographic references [Boyanov et al., 1991; Boyanov et al., 1993a; Boyanov et al., 1993b; Boyanov et al., 1993c; Tsankov et al., 1995a; Tsankov et al., 1995b]. Pre-Cambrian, Paleozoic, Mesozoic, and Neogene rocks are revealed on the earth's surface. Pre-Cambrian (Arhai) rocks are discovered in the area of the villages Slavyanin, Elhovo, Gorno Novo selo, Dolno Novo selo, and Malko Dryanovo. The rocks are represented by gneisses, gneiss-schist, and amphibolites from the Ardenska group. Paleozoic (Carbon) rocks are discovered in the area of Medovo village - different types of granites of the South Bulgarian granitoid group. Mesozoic Upper Cretaceous rocks from the Flishka formation (limestones, sandstones, and marls) are discovered in the area of the villages of Vinarovo, Izvorovo, Sredno Gradishte, and Stoyan- Zaimovo. Upper Cretaceous rocks from the Volcanogenic-Sedimentary Association (tuffs, sandstones, marls, and limestones) are situated in the area of the Sarnevets village, by Upper Cretaceous medium-acid volcanic bodies, mostly andesites. Associated with the volcanic bodies are hydrothermal solutions from which hematite iron ores have been deposited in the Sarnevets deposit, located between the villages of Sarnevets and Malko Dryanovo. The ore bodies are revealed on the surface, coloring soil in a characteristic red due to hematite weathering. Traces of old mining have also been described [Kanurkov, 1988; Tsankov et al., 1995b; Kostova, 2017]. Upper Cretaceous rocks from the Flishka carbonate formation (limestone, sandy limestone, marl, and sandstone) are discovered in the area of the 
villages of Sladak Kladenets, as well as south of the villages of Slavyanin, Gorno Novo Selo, Dolno Novo Selo, and Elhovo. Neozoic (Oligocene) rocks from the Merichlerska limestone formation (limestones) are described in the area of Malko Tranovo village. Neozoic (Neogene) rocks from the Akhmatovska Formation (gravels, sands, and clays) are found in the area of Dimitrievo village. There are no data for the presence of modern clay deposits in the studied area.

Based on the selected archeological and geological sites, preliminary routes for fieldwork have been prepared, to create an optimal opportunity to visit each of them.

\subsection{Fieldwork}

During the fieldwork 23 archeological sites were visited. The location of each one is known (available coordinates), and to find them we worked with mobile devices with an installed mobile version of GIS software (ArcPad).

The visited sites are 23, from which 17 were registered in our previous project (20142017), the others have been registered and investigated by other researchers during the last two decades or earlier. The number, geographical location (village), and the type of archaeological sites are as follows: №1 Slavyanin, settlement; №2 Medovo, settlement; №3 Vinarovo, settlement; №4 Sladuk kladenets, settlement; №5 Elhovo, Roman villa Chatalka; №6 Malko Tranovo, open settlement; №7 Slavyanin, Roman tomb; №8 Dimitrievo, Emporion Pizos; №9 Izvorovo, Malkoto gradishte, fortified settlement; №10 Izvorovo, Golyamoto gradishte, fortified settlement; №11 Izvorovo, settlement; №12 Sredno gradishte, fortified settlement; №13 StoyanZaimovo settlement; №14 Gorno Novo selo, Sveti Nikola, fortified settlement; №15 Gorno Novo selo, church Extra Muros 1; №16 Gorno Novo selo, church Extra Muros 2; №17 Gorno Novo selo, fortified settlement; №18 Gorno Novo selo, Topra Asra, fortified settlement; №19 Dolno Novo selo, settlement; №20 Sarnevets, settlement; №21 Sarnevets, settlement; №22 Malko Dryanovo, settlement; №23 Medovo, settlement.

Today, most of the sites (16) are located on the territory of arable agricultural lands (Fig. 1. 1). Archaeological structures above the earth's surface have been preserved in only seven sites (Figs. 2-8).

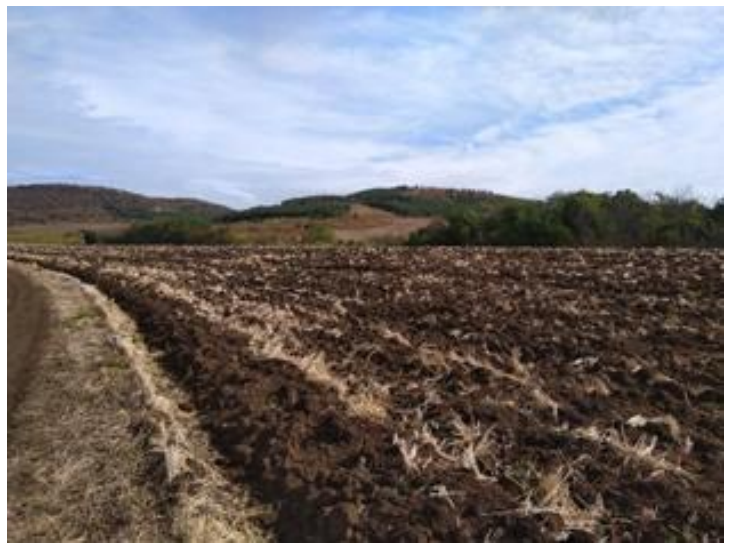

Fig. 1 Site №4

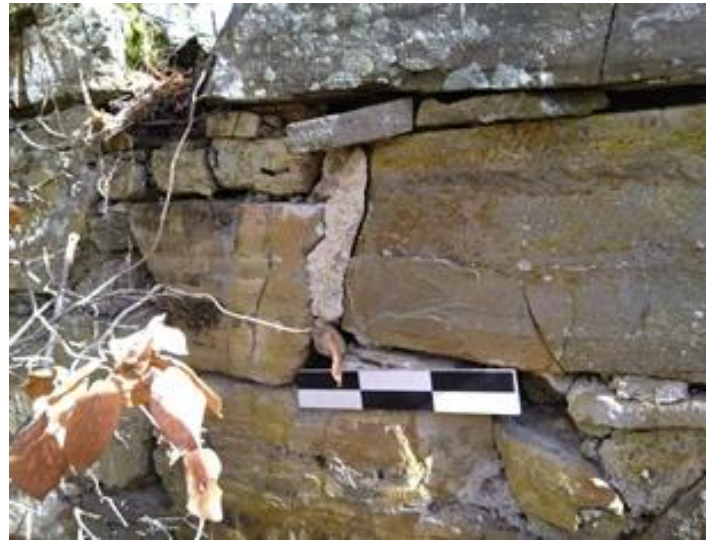

Fig. 2 Site №5 


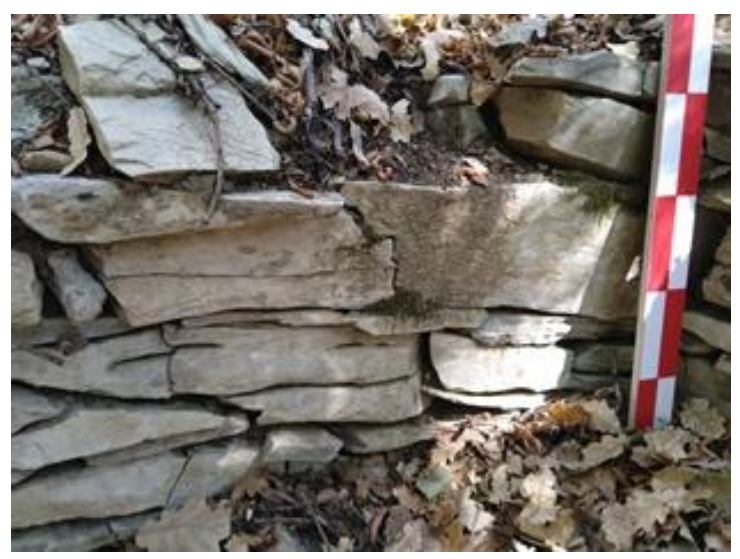

Fig. 3 Site №9

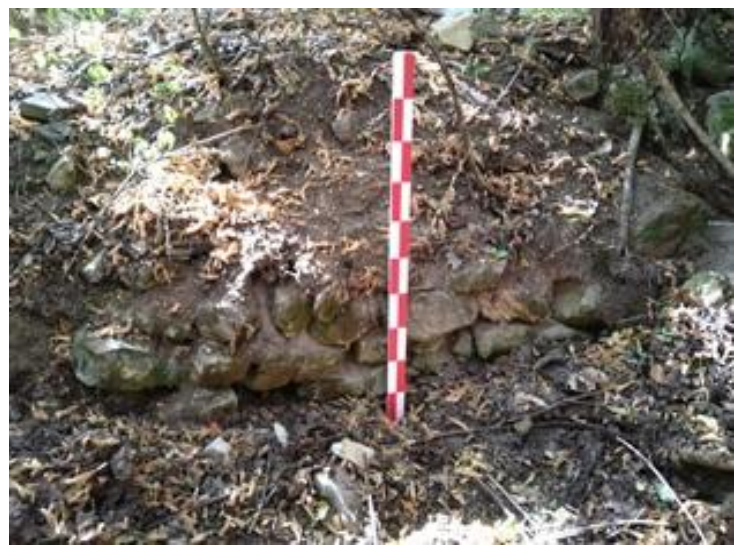

Fig. 5 Site №14



Fig. 7 Site №16

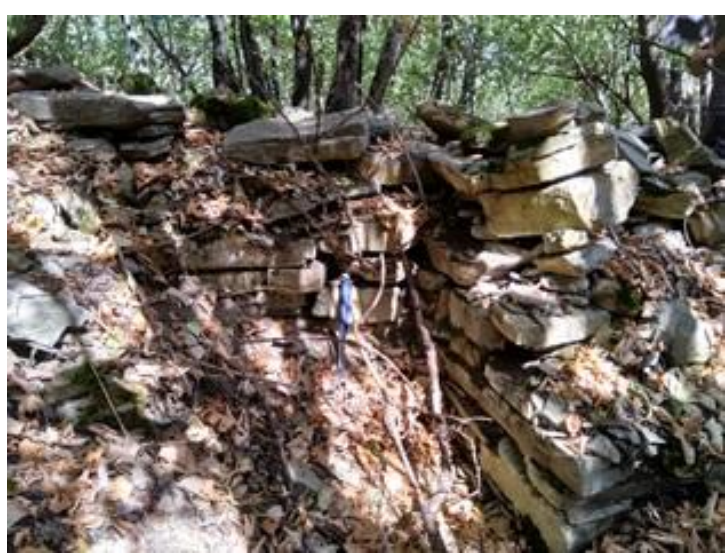

Fig. 4 Site №12

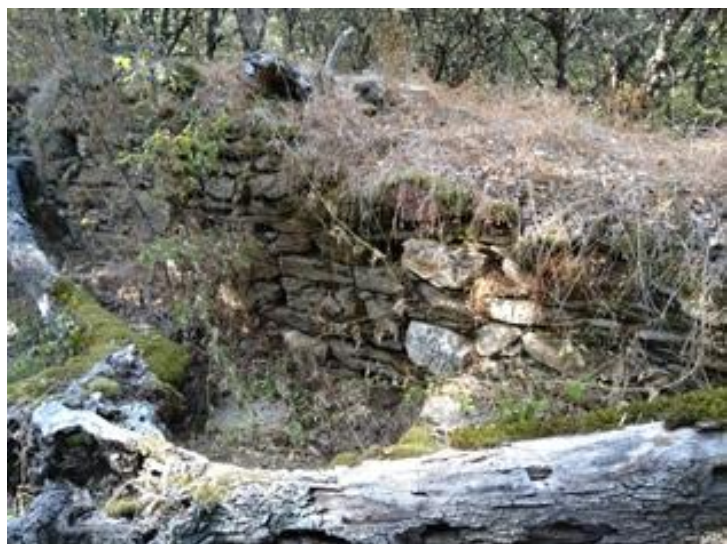

Fig. 6 Site №15



Fig. 8 Site №17

The collected archaeological samples include building ceramic (bricks and different types of tiles), pottery, mortars, waste products from metallurgical activity (slags).

The geological sampling includes rocks, and minerals, preliminary defined as potential raw materials for composite archaeological samples were sampled. During the fieldwork, the geographical linking of rock deposits with the visited archaeological sites was made, as well as identification of rock materials used as a building material for the construction of walls of houses, fortress walls, etc. 
The collected gneisses from the Ardenska group are revealed on the earth's surface at sites №1, 5, 14, 15, 16, 17, 18, 19, 22. Gneisses are suitable for wall constructions - they can easily be split into larger and smaller blocks. The main minerals in gneisses are quartz, feldspar, and mica. During physical weathering, they are mechanically crushed into a sand fraction with practically unchanged mineral composition, which is suitable for mortar, plaster, and ceramics preparation. After gneisses chemical weathering, the quartz remains unchanged. Micas (muscovite $\mathrm{KA}_{12}\left(\mathrm{AlSi}_{3} \mathrm{O}_{10}\right)(\mathrm{OH})_{2} /$ biotite $\left.\mathrm{K}(\mathrm{Mg}, \mathrm{Fe})_{3}\left(\mathrm{AlSi}_{3} \mathrm{O}_{10}\right)(\mathrm{OH}, \mathrm{F})_{2}\right)$ are changed to clay mineral kaolinite $\mathrm{Al}_{2} \mathrm{Si}_{2} \mathrm{O}_{5}(\mathrm{OH})_{4}$. Feldspars are changed according to the following scheme: sericite $\mathrm{KAl}_{2}\left(\mathrm{AlSi}_{3} \mathrm{O}_{10}\right)(\mathrm{OH})_{2} \rightarrow$ kaolinite $\left.\mathrm{Al}_{2} \mathrm{Si}_{2} \mathrm{O}_{5}(\mathrm{OH})_{4}\right) \rightarrow$ aluminum hydrates $+\mathrm{SiO}_{2}$. Thus formed, clays can be used as a raw material for the ceramics and wall plasters production. The gneisses chemical weathering takes place in river beds, forming local clay lenses. Similar formations probably existed in the past in many places in Omurovska River's bed and its tributaries (the largest tributary of the Novoselska River), which passes through the rocks of the Ardenska Group. If the pottery found at the sites had been locally produced, the clay is likely of such origin, as no industrial clay deposits were known in the study area.

Collected limestones and marls from the area of Izvorovo village and limestones and sandstones from the area of Sredno Gradishte village belong to the Flishka formation. They outcrop the earth's surface at sites №3, 9, 10, 11, 12, 13. Limestones and marls are of low hardness and easy to process which makes them suitable for wall construction. Their chemical composition $\left(\mathrm{CaCO}_{3}\right)$ defined them as a major source of mortar production.

The collected hematite from the area between the villages of Sarnevets and Malko Dryanovo is the most probable mineral iron reduction. Evidence for such a process are the documented old mines and the slag found.

Upper Cretaceous rocks from Flishka carbonate formation (limestones from the region south of the villages Gorno Novo selo and Elhovo; sandstones from the region south of the village Elhovo) were collected. These rocks revealing on the earth's surface at sites №4 and 7 and rocks revealing on the earth's surface near sites №14, 15, 16, 17, 18, 19. Limestones and sandstones are suitable both for wall construction and for mortar production.

Oligocene limestones from the Merichlerska limestone formation are collected from the area of Malko Tranovo village. The limestones revealing on the earth's surface in the area of the village. They are suitable both for construction and for mortar production.

The identification of building material for wall construction was made. The stone wall at site №5 is of limestone and sandstone, welded with mortar (Fig. 2). On the earth's surface are revealed only gneisses, which were not used for the walls. To the south, near to the site №5 on the earth's surface, the Upper Cretaceous limestones and sandstones from the Flishka carbonate formation were discovered, which were used for the wall construction and most probably for mortar preparation (limestones). At sites, №9 (Figs. 3) and №10 are preserved walls of predominantly limestone and a small quantity of marl, where at site №12 (Fig. 4) - the walls are from limestone, red and yellow sandstones. These rocks are from the Flishka carbonate formation and outcrop on the earth's surface at the sites. The presence of limestones and marls allows not only their use for the mortar preparation but also their use for construction - limestone is a soft rock, it is easy to get smooth surfaces of blocks, suitable for construction. At sites №14, №15, №16, and №17 (Figs. 5 - 8) are preserved stone walls of predominantly gneisses and minor quantity limestones. The gneisses are revealed on the earth's surface. The limestones belong to the Flishka carbonate formation, discovered in the immediate vicinity. The lower limestone 
quantity in the walls suggests that its presence is mainly related to the preparation of discovered mortar.

\subsection{Post-fieldwork}

Chronological determination of the collected archaeological samples was made during the post-fieldwork. From the expected 7 archeological periods, samples from 5 were collected: Chalcolithic, Iron Age (Early Iron Age $-12^{\text {th }}-7^{\text {th }}$ century BC and Late Iron Age $-6^{\text {th }}-1^{\text {st }}$ century BC), Roman Age, Late Antiquity, and Bulgarian Renaissance. The earliest samples date back to Chalcolithic period and were found in sites №1 and №5. Iron Age materials have been diagnostic in four sites: №2, №3, №4, and №20. Samples from the Roman age were determinate in six objects: №4, №5, №6, №7, and №8. From late Antiquity, the largest number of samples were found, collected from 15 sites. During post-fieldwork, the sample description was made. Three groups of archaeological samples are collected:

- building materials - bricks, different types of tiles, mortar and clay plaster of Roman age and late Antiquity;

- pottery - different vessel fragments from all five archaeological periods;

- slags - traces of iron production.

The geological samples (different types of gneisses, marls, limestones, and sandstones) from different localities as possible local raw materials for building materials and pottery production, and hematite as raw ore for iron production.

All collected samples are cataloged, supporting the creation of appropriate sample sets for analysis by archaeological chemistry analytical techniques.

\section{Conclusion}

The created archeological and geological approaches allow for efficient and targeted work. A purposeful selection of archeological and geological sites and collection of samples was made:

- archaeological sites of confirmed archaeological significance of all seven epochs proven and described in the literature in the area of interest;

- geological sites with contemporary locations of the earth's surface are identified to search potential raw materials for archaeological materials preparation;

- the preliminary routes for fieldwork have been prepared to create an optimal opportunity to visit each of them;

- successful collection of most of the planned sample types, namely: (i) Archaeological samples from 23 sites and five archeological periods. The samples are of all planned types - building ceramic (bricks and tiles), building materials (mortar and clay plaster), pottery (different vessel fragments), iron slags. (ii) Geological samples of all found localities of rocks and minerals predefined as possible raw material for archaeological samples production.

Such methodical work allowed the creation of representative sample sets for investigations with archaeological chemistry analytical techniques. This basis provides an opportunity for adequate interpretation of analytical data to achieve the project objectives - fundamental knowledge of material culture in different archaeological periods and people's knowledge of the ancient environment. 


\section{Acknowledgments}

This work was funded by the Bulgarian Science Research Fund (grant number KP-06N39/9).

Author contributions: B. D. and B. K. wrote the manuscript, which was read, revised and approved by all co-authors.

Conflict of interest: The authors declared no conflict of interest.

\section{REFERENCES}

Boyanov I., A. Goranov, J. Shilyafova, M. Ruseva. Geolojki karti na Bulgaria, M 1:100000, Karten list Dimitrovgrad. [Geological maps of Bulgaria, M 1:100000, Map sheet Dimitrovgrad]. 1991.

Boyanov I., A. Goranov, J. Shilyafova, M. Ruseva. Obyasnitelbna zapiska kum geolojka karta na Bulgaria M 1:100000, Karten list Dimitrovgrad. [Explanatory note to Geological maps of Bulgaria, M 1:100000, Map sheet Dimitrovgrad]. Bolid-Sofia. 1993a.

Boyanov I., J. Shilyafova, A. Goranov, M. Ruseva, T. Nenov. Geolojki karti na Bulgaria, M 1:100000, Karten list Chirpan. [Geological maps of Bulgaria, M 1:100000, Map sheet Chirpan]. 1993b.

Boyanov I., J. Shilyafova, A. Goranov, M. Ruseva, T. Nenov. Obyasnitelbna zapiska kum geolojka karta na Bulgaria M 1:100000, Karten list Chirpan. [Explanatory note to Geological maps of Bulgaria, M 1:100000, Map sheet Chirpan]. Bolid-Sofia. 1993c.

Dumanov B., Zh, Uzunov, I. Dimitrova, B. Atanasov, I. Boyanov, D. Yankov, P. Manov, N. Karastoyanova, L. Manoilova. Izdirvane na arheologicheski obekti na teritoriata na obshtini Bratia Daskalovi, Chirpan I Stara Zagora. [Search for archeological sites on the territory of the municipalities of Bratya Daskalovi, Chirpan and Stara Zagora]. Arheologicheski otkritia I razkopki za 2015. [Archaeological discoveries and excavations in 2015]. Sofia. 2016. 864-867.

Dumanov, B. Selishtniat kompleks pri s. Gorno Novo selo - regionalen, upravlenski, ikonomicheski I religiozen tsentar v tsentralnia dial na Sarnena Sredna gora. [The settlement complex near the village of Gorno Novo selo - a regional administrative, economic and religious center in the central part of Sarnena Sredna Gora.]. V: SARCHUSAIR. Lokalizirane I eksperimentalna rekonstruktsia na drevni putishta I habitati, Red. B. Bumanov [In B. Dumanov (Ed): SARCHUS-AIR. Localization and experimental reconstruction of ancient roads and habitats]. Sofia, Askoni-Izdat OOD [LTD]. 2017a, 5562.

Dumanov, B., Zh, Uzunov, I. Dimitrova, Ch. Lalov. Kataog na registriranite arheologicheski obekti ot terenni izdirvania prez 2015 I 2017. [Catalog of the registered archeological sites from field archeological excavations in 2015 and 2017]. V: SARCHUS-AIR. Lokalizirane I eksperimentalna rekonstruktsia na drevni putishta I habitati, Red. B. Bumanov [In B. Dumanov (Ed): SARCHUS-AIR. Localization and experimental reconstruction of ancient roads and habitats]. Sofia, Askoni-Izdat OOD [LTD]. 2017b, 77-114.

Glascock M. D., R.J. Speakman, R. S. Popelka-Filcoff, (Eds). Archaeological Chemistry. Analytical Techniques and Archaeological Interpretation. ACS symposium series 968. American Chemical Society, Distributed by Oxford University Press. 2006. 571. 
Goffer Z., 2nd Ed. Archaeological chemistry. Chemical analysis: A series of monographs on analytical chemistry and its applications. Wiley \& Sons, Inc., Hoboken, New Jersey. 2007. 623.

Issi A., C. Serkaya, V. Uz, A. N. Bilgen. Investigation of the Achaemenid period pottery production technology from the Seyitömer Mound (Kütahya, Turkey). Transactions on The Built Environment, 168. 2013. 607-616.

Kanurkov, G. Zelezorudnite nahodishta v Bulgaria. [The iron deposits of Bulgaria]. Tehnika, Sofia. 1988. 173-175.

Kostova B. Geolozka harakteristika na Srednogorskata zona. Drevni minni izrabotki na teritoriata na Sarnena Sredna gora. [Geological characteristics of the Srednogorska zone. Ancient mining works on the territory of Sarnena Sredna gora mountain]. V: SARCHUS-AIR. Lokalizirane I eksperimentalna rekonstruktsia na drevni putishta I habitati, Red. B. Bumanov [In B. Dumanov (Ed): SARCHUS-AIR. Localization and experimental reconstruction of ancient roads and habitats]. Sofia, Askoni-Izdat OOD [LTD]. 2017. 3135 .

Krapukaitytė A., S. Tautkus, A. Kareiva, E. Zalieckienè. Thermal analysis - a powerful tool for the characterization of pottery. Chemija. 19 (2). 2008. 4-8.

Naseerutheen A., R. Ravisankar, G.Raja Annamalai, A.Chandrasekaran. Application of TG-DTA to study of Ancient Potteries from Kaveripakkam, Vellore district, Tamilnadu, India. Canadian Journal of Basic and applied sciences. 01. 2013. 44-48.

Neff H. Theory, sampling, and analytical techniques in the archaeological study of prehistoric ceramics. American Antiquity, 58(1), 1993. 23-44.

Palanivel R., U. Rajesh Kumar. Thermal and spectroscopic analysis of ancient potteries. Romanian Journal of Physics. 56 (1-2). 2009. 195-208.

Palanivel R., U. Rajesh Kumar. The mineralogical and fabric analysis of ancient pottery artifacts. Cerâmica. 57. 2011. 56-62.

Pollard M., C. Heron. 2nd Ed. Archaeological Chemistry. The Royal Society of Chemistry, Thomas Graham House, Science Park, Milton Road, Cambridge CB4 0WF, UK. 2008. 438.

Roberts, B.W., Thornton Ch. P. (Eds.). Archaeometallurgy in Global Perspective. Methods and Syntheses. Springer New York Heidelberg Dordrecht London. 2013. 868.

Sáncheza A. M., M.J. Nuevoa, M.A. Ojedab, S. Guerra Millánc, S. Celestinod, E. Rodríguez Gonzálezd. Analytical techniques applied to the study of mortars and coatings from the Tartessic archaeological site "El Turuñuelo" (Spain). Radiation Physics and Chemistry. $2020,108341$.

Tsankov Ts., L. Philopova, N. Katskov. Geolojki karti na Bulgaria, M 1:100000, Karten list Kazanlak. [Geological maps of Bulgaria, M 1:100000, Map sheet Kazanlak]. 1995a.

Tsankov Ts., L. Philopova, N. Katskov. Obyasnitelbna zapiska kum geolojka karta na Bulgaria M 1:100000, Karten list Kazanlak. [Explanatory note to Geological maps of Bulgaria, M 1:100000, Map sheet Kazanlak]. ET-Avers, Sofia. 1995b.

Uzunov Zh. Metodi za terenni izdirvania pri terenni izsledvania na arheologicheski obekti v raiona na Sarnena Sredna gora. [Research methods in the field excavations of archeological sites in the area of Sarnena Sredna gora mountain]. V: SARCHUS-AIR. Lokalizirane I eksperimentalna rekonstruktsia na drevni putishta I habitati, Red. B. Bumanov [In B.

https://doi.org/10.33919/ansd.20-21.6.6 
Dumanov (Ed): SARCHUS-AIR. Localization and experimental reconstruction of ancient roads and habitats]. Sofia, Askoni-Izdat OOD [LTD]. 2017a, 35-37.

Uzunov Zh., I. Dimitrova, B. Dumanov. Resultati ot terennite arheologicheski izdirvania na arheologicheski obekti $\mathrm{v}$ rabotnia raion. [Results from the field archeological excavations of archeological sites in the working area.] V: SARCHUS-AIR. Lokalizirane I eksperimentalna rekonstruktsia na drevni putishta I habitati, Red. B. Bumanov [In B. Dumanov (Ed): SARCHUS-AIR. Localization and experimental reconstruction of ancient roads and habitats]. Sofia, Askoni-Izdat OOD [LTD]. 2017b. 37-49. 